\title{
Studi Deskriptif: Persepsi Mahasiswa Ilmu Forensik terhadap Konsep Cyberstalking
}

\section{Descriptive Study: Forensic Science Students Perceptions of the Concept of Cyberstalking}

\author{
Ainun Jaryah Bahrir* \\ Ilmu Forensik, Sekolah Pascasarjana, Universitas Airlangga, Indonesia \\ Diterima: 28 Januari 2020; Disetujui: 21 Maret 2020; Diterbitkan: 01 Juli 2020.
}

\begin{abstract}
Abstrak
Cyberstalking adalah perilaku yang menjurus pada penyerangan wilayah privasi seseorang yang berulang-ulang melalui surat elektronik atau komunikasi berbasis computer dengan maksud untuk mengendalikan, memaksa, mengintimidasi, menganggu atau mengancam. Tujuan penelitian ini adalah untuk menggambarkan pemahaman mahasiswa ilmu forensic tentang konsep cyberstalking: kriteria obyek dari penelitian ini adalah mahasiswa ilmu forensik yang masih aktif dan telah mengambil mata kuliah cybercrime. Metode penelitian ini menggunakan kuantitatif deskriptif. Subjek dalam penelitian ini diperoleh melalui purposive sampling dengan total 36 mahasiswa. Teknik pengumpulan data penelitian adalah dengan menyebarkan tertutup. Tenik analisis data penelitian adalah teknik analisis deskriptif, mendeskripsikan dan menggambarkan data yang diperoleh dengan menggunakan table dan gambar. Hasil penelitian ini menunjukkan bahwa mahasiswa ilmu forensik telah memiliki persepsi yang benar mengenai cyberstalking. Mayoritas mahasiswa bisa membedakan pernyataan dengan indikasi cyberstalking dan bukan cyberstaking.
\end{abstract}

Kata Kunci: Persepsi, Cyberstaking, Cybercrime, Ilmu Forensik

\begin{abstract}
Cyberstalking is behavior that leads to repeated invasion of one's privacy by electronic mail or computer-based communication with a view to controlling, coercing, intimidating, harassing, or threatening. The purpose of this study is to describe the understanding of forensic science students about the concept of cyberstalking; the object criteria of this study are forensic science students who are still active and have taken cybercrime courses. This research method uses descriptive quantitative. Subjects in this study were obtained through purposive sampling with a total of 36 students. The technique of collecting research data is by distributing closed questionnaires. Research data analysis technique is a descriptive analysis technique, describing data obtained using tables and graphs. The results of this study indicate that forensic science students already have the correct perception of cyberstalking. The majority of students can distinguish statements with indications of cyberstalking and not cyberstalking.

Keywords: Perception, Cyberstalking, Cybercrime, Forensic Science
\end{abstract}

How to Cite: Bahrir, A.J. (2020). Studi Deskriptif: Persepsi Mahasiswa Ilmu Forensik terhadap Cyberstalking. PERSPEKTIF, 9(2): 219-228

\footnotetext{
*Corresponding author:

E-mail: aibahrir.22@gmail.com
}

ISSN 2085-0328 (Print) ISSN 2541-5913 (online) 


\section{PENDAHULUAN}

Pada 2019, Asosiasi penyelenggara Jasa Internet Indonesia dan Polling Indonesia menyatakan penetrasi pengguna internet telah mencapai 171,18 juta dari total 264,16 juta penduduk Indonesia, $64,8 \%$ atau lebih dari setengah penduduk indonesia telah melakukan akses internet. Peningkatan sebesar $10 \% \quad(27,91$ juta $)$ pengguna dibandingkan dengan data 2018. Indonesia menempati posisi ke-5 sebagai pengguna internet terbesar di dunia dengan durasi penggunaan 8 jam 36 menit perhari. Usia pengguna internet di Indonesia berkisar dari 5 hingga 65 tahun ke atas; di dominasi oleh pengguna usia 15-24 tahun dan diikuti oleh pengguna usia 25-34 tahun. 93.9\% menggunakan handphone saat mengakses internet (Merdeka.com, 2019; APJII, 2019).

Generasi muda saat ini sangat terobsesi dengan teknologi digital dan dengan cepat berkembang menjadi sebuah generasi baru yang biasa disebut warga dunia maya (netizen). Maraknya situs jejaring sosial dengan aplikasinya membuat semua aktivitas yang dulunya hanya bisa digunakan pada laptop, sekarang sudah bisa digunakan menggunakan smartphone (Tennakoon, Saridakis, \& Mohammed, 2017).

Mudahnya akses internet di era globalisasi memiliki dampak positif dan negatif, globalisasi ini menciptakan dunia dengan arus informasi mengglobal dan tanpa batas. Dampak positif Internet adalah penggunaan komunikasi lewat pesan serta mendapatkan informasi di media sosial lebih murah dan cepat. Media sosial dan internet adalah satu hal yang tidak bisa dipisahkan, bahkan komunikasi lewat pesan juga sering dilakukan di media sosial. Media sosial selain tempat memperoleh informasi juga telah menjadi sebuah gaya hidup, mengeksistensikan diri di media sosial dengan membagian aktivitas keseharian adalah sebuah trend terbaru saat ini. Dampak negatif internet adalah penyebaran informasi yang ekstrem menyebabkan tindak kriminal yang menggunakan teknologi komputer terjadi dengan mudah (Ambarsari, Fadhila, \& Christiana, 2017; APJII, 2019; Yusaputra, Sari, Utama, \& Husnuzan, 2018).

Cyberstalking adalah salah satu tindak criminal yang terjadi di internet. Cyberstalking didefinisikan sebagai perilaku menyimpang yang menyerang wilayah privasi seseorang menggunakan media internet seperti e-mail, media sosial dan komunikasi internet lainnya secara berulang dengan tujuan untuk mengendalikan atau mengontrol, mengintimidasi, mengancam, memaksa dan menganggu (Begotti \& Maran, 2019).

Cyberstalking bisa dikatakan sebagai bentuk terbaru dari perilaku kriminal menguntit, fenomena menguntit telah ada selama dekade terakhir dan termasuk masalah sosial dan politik. Menguntit mencakup berbagai perilaku langsung atau tidak langsung yang menimbulkan rasa tidak aman seperti mengikuti, muncul di rumah atau kantor, merusak properti, meninggalkan pesan tertulis atau benda dan melakukan panggilan telepon berkalikali. Berkembangnya zaman menyebabkan terjadinya evolusi atau mentransformasi perilaku kriminal ini menjadi bentuk terbaru bahkan menyediakan sebuah metode tambahan untuk pelaku ketika menargetkan korban mereka (Alexy, Burgess, \& Baker, 2005).

Cyberstalking mempengaruhi kesehatan mental serta kesejahteraan korbannya, seperti kecemasan dan ketakutan yang serius secara terus menerus, insomnia, merasa marah, sakit hati, dikhianati, paranoid dan depresi, bahkan dalam beberapa kasus membuat korban mengubah kebiasaan sehariharinya (Maran \& Begotti, 2019).

Pada penelitian Reyns, Henson \& Fisher sebelumnya mengenai hubungan korban dan pelaku memaparkan bahwa pelaku tidak hanya orang asing atau orang yang tidak dikenal, akan tetapi dalam beberapa kasus pelaku adalah teman, 
kenalan, mantan pasangan bahkan pasangan. Sedangkan pada penelitian Cavezza \& Mcewan menyebutkan bahwa dari 261 kasus cybercrime, 36 kasus diidentifikasi sebagai cyberstalking dan pelaku adalah 94\% laki-laki (Reyns, Henson \& Fisher, 2012; Cavezza \& Mcewan, 2014).

Di Indonesia penelitian dengan topik cyberstalking telah dilakukan oleh Ambasari, Fadhila \& Christiana, dalam penelitian tersebut peneliti melakukan peer-group konseling untuk mengurangi intensitas munculnya perilaku cyberstalking pada remaja. Setelah melalui sesi konseling, empat dari enam siswa berhasil mengurangi tendensi perilaku cyberstalking. Selain itu, penelitian sejenis juga dilakukan Yusaputra, Sari, Utama, \& Husnuzan. Pada penelitiannya memaparkan bahwa banyak faktor yang melatarbelakangi cyberstalking, bisa dari diri sendiri, orang lain bahkan lingkungan disekitarnya (Ambarsari, Fadhila, \& Christiana, 2017; Yusaputra, Sari, Utama, \& Husnuzan, 2018).

Beberapa indikator cyberstalking seperti mengendalikan, mengintimidasi, mengancam, memaksa atau mengganggu adalah hal yang sering dilakukan tanpa sadar dalam sebuah relasi, baik dengan pasangan, mantan bahkan orang asing yang tidak dikenal. Mahasiswa ilmu forensik yang termasuk dalam golongan usia pengguna internet terbesar di Indonesia dengan pengetahuan bidang ilmu kejahatan teknologi di perkuliahannya tentu saja memiliki persepsi terhadap konsep cyberstalking.

\section{METODE PENELITIAN}

Metode penelitian yang digunakan pada penelitian ini adalah metode statistik deskriptif, metode yang mencakup caracara mengolah, menyusun, mengatur serta meganalisis data angka sehingga memberikan gambaran yang ringkas, jelas dan teratur mengenai suatu fenomena atau keadaan (Sholikhah, 2016).
Peneliti memberikan angket tertutup atau berstruktur, di mana berisikan pernyataan yang telah disertai pilihan jawaban, sampel diharapkan memilih pilihan yang paling sesuai (Kusuma, 2011). Pernyataan dalam angket berjumlah 18 aitem, 9 aitem favorable (positif) dan 9 aitem unfavorable (negatif) berisi situasi hipotesis mengenai cyberstalking.

Sampel dalam penelitian ini adalah mahasiswa ilmu forensik. Teknik pengambilan sampel yang digunakan adalah purposive sampling, yaitu pengambilan sampel yang memilih kelompok sampel yang sesuai dengan karakteristik tertentu dan sifat-sifat tertentu yang telah diketahui sebelumnya. Karakteristik sampel yang dimaksudkan adalah mahasiswa ilmu forensik yang telah mengambil mata kuliah ilmu kejahatan teknologi.

Proses pengambilan data berlangsung selama tiga minggu, sebelumnya peneliti menghubungi sampel yang telah sesuai dengan kriteria untuk menanyakan kebersediaannya, lalu menyebarkan angket persepsi tersebut.

Peneliti mengambil sampel sebanyak 36 mahasiswa, total keseluruhan populasi yang sesuai dengan kriteria yang telah ditentukan. Data primer pada penelitian ini adalah data angket atau kuisioner yang telah dijawab oleh responden meliputi situasi hipotetis yang berkaitan dengan persepsi mereka terhadap konsep cyberstalking, sedangkan data sekunder berupa data demografi dari mahasiswa ilmu forensik.

\section{HASIL DAN PEMBAHASAN}

Total 36 sampel telah melakukan pengambilan data, 7 laki-laki (25\%) dan 27 perempuan (75\%); 21 mahasiswa berusia <25 tahun (58.3\%) dan 15 mahasiswa berusia 25-35 tahun (41.7\%). Latar belakang pendidikan sampel penelitian yaitu pendidikan medis, eksakta, dokter hewan, antropologi lalu psikologi. 
Tabel 1 Data Demografi Agama

\begin{tabular}{|c|c|c|c|}
\hline No & Agama & Frequency & $\%$ \\
\hline 1 & Islam & 25 & $69.4 \%$ \\
\hline 2 & Kristen & 5 & $13.9 \%$ \\
\hline 3 & Katolik & 5 & $13.9 \%$ \\
\hline \multirow[t]{2}{*}{4} & Kong hu cu & 1 & $2.8 \%$ \\
\hline & Total & 36 & $100 \%$ \\
\hline
\end{tabular}

bahwa mayoritas sampel beragama islam, Indonesia sebagai Negara dengan penduduk mayoritas muslim memiliki pemahaman yang patriarki. Patriarki merupakan sebuah sistem di mana lakilaki dewasa ditempatkan pada posisi yang terpenting atau sentral. Sistem ini memposisikan bahwa laki-laki harus selalu memimpin, menguasai dan mengatur pasangannya (Nurmila, 2015). Beberapa pernyataan pada angket yang telah disebarkan menempatkan situasi hipotesis mengenai sebuah hubungan antara pasangan atau mantan pacar. Sampel lakilaki cenderung menjustifikasi situasisituasi tertentu yang mengandung indikasi seperti menguasai, dan mengatur. Lebih detailnya akan dibahas pada setiap tabel hasil angket berikut.

\section{Persepsi Konsep Cyberstalking}

Beberapa situasi hipotesis diberikan kepada mahasiswa ilmu forensik dalam menentukan label tindakan tertentu sebagai cyberstalking, situasi hipotesis tersebut dibagi menjadi tiga sudut pandang, sebagai pasangan, mantan pacar dan orang asing.

Tabel 2 Data Hasil Respon Sudut Pandang Pasangan

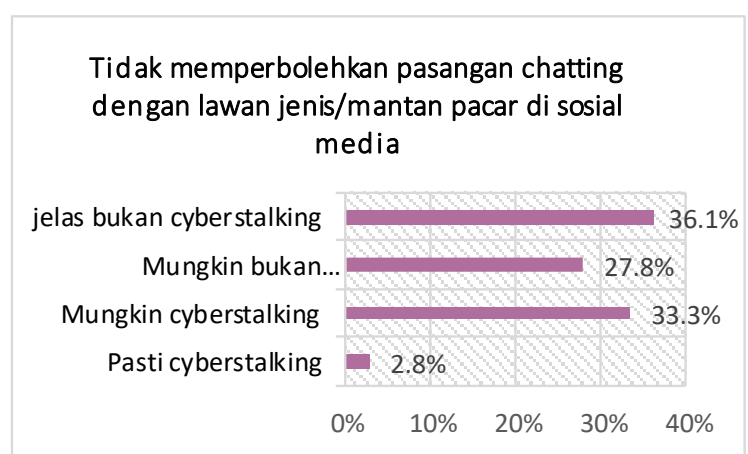

Respon mahasiswa ilmu forensik terhadap situasi hipotesis pada tabel di samping, sebagian besar mahasiswa menganggap bahwa indikator mengendalikan pada situasi tersebut tidak

termasuk dalam konsep cyberstalking. 4 dari total 9 responden laki-laki memilih jawaban jelas bukan cyberstalking pada situasi ini, hanya 1 dari 36 responden yang memilih pasti cyberstalking pada situasi ini.

Tabel 3 Data Hasil Respon Sudut Pandang Pasangan

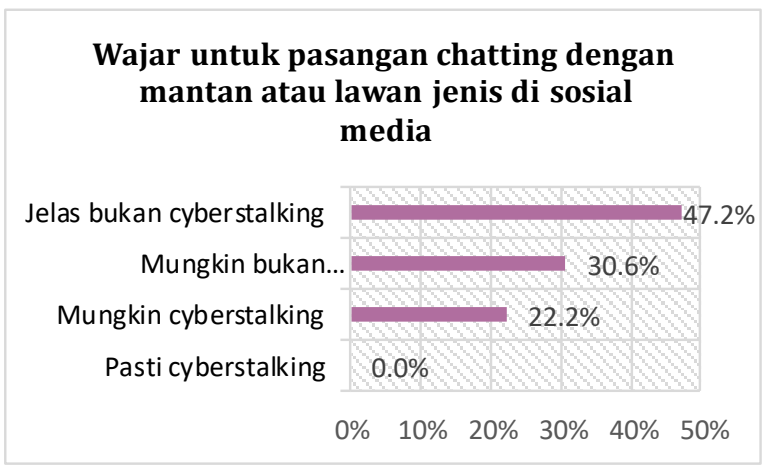

Tidak ada responden yang memilih pilihan pasti cyberstalking pada situasi hipotesis di angket ini, akan tetapi 8 responden wanita masih kebingungan dalam mengerti konsep cyberstalking, angket ini merupakan situasi hipotesis unfavorable, di mana pernyataan yang diberikan bersifat normal atau bukan indikasi cyberstalking.

Tabel 4 Data Hasil Respon Sudut Pandang Pasangan

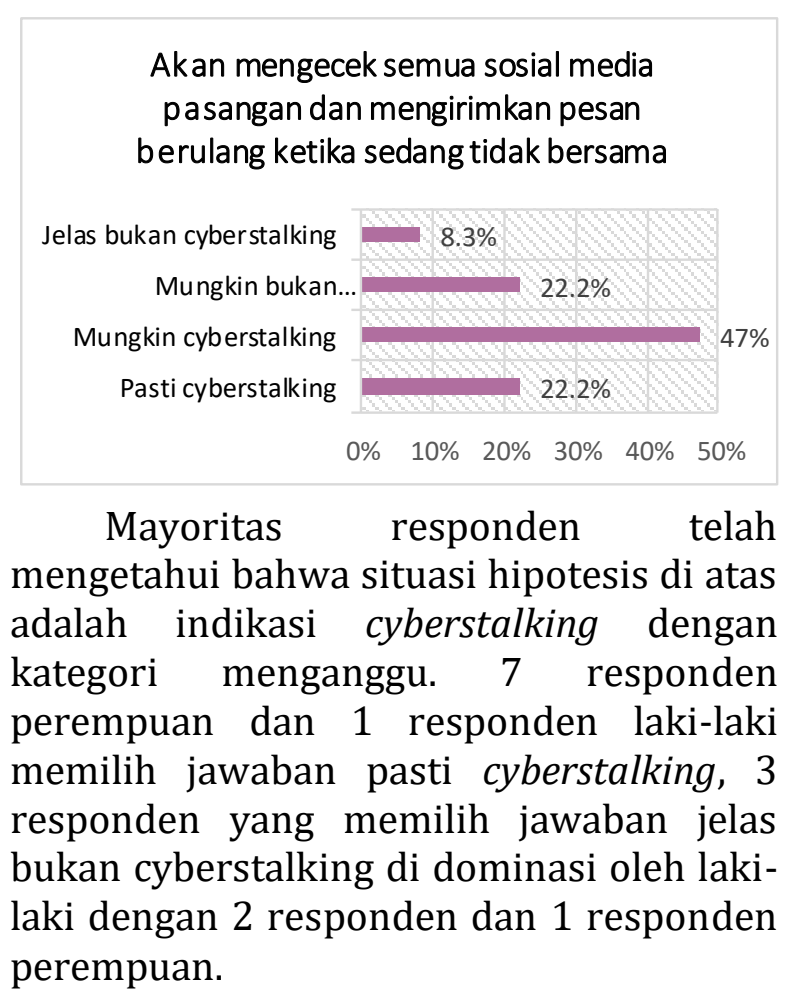


Tabel 5 Data Hasil Respon Sudut Pandang Pasangan
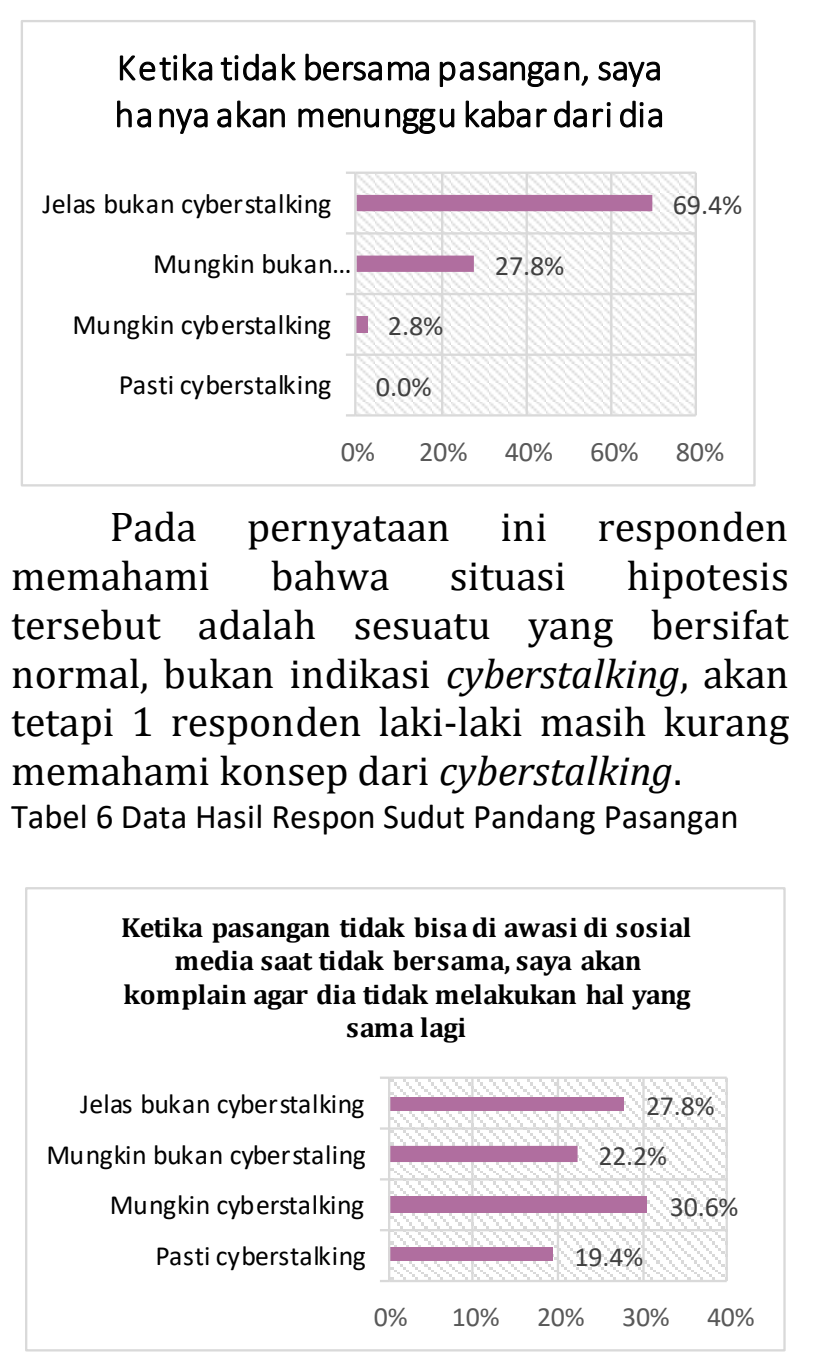

Pernyataan pada situasi hipotesis ini memiliki hasil respon yang menarik. Responden yang menganggap bahwa situasi ini masuk dalam label cyberstalking dan bukan cyberstalking sama rata, total 50:50, walaupun pada situasi ini memiliki Indikator mengancam pada penyataannya. Mayoritas responden perempuan yaitu 16 dari 27 melabelkan cyberstalking, sedangkan mayoritas responden laki-laki 7 dari 9 melabelkan pernyataan ini sebagai bukan cyberstalking.
Tabel 7 Data Hasil Respon Sudut Pandang Pasangan

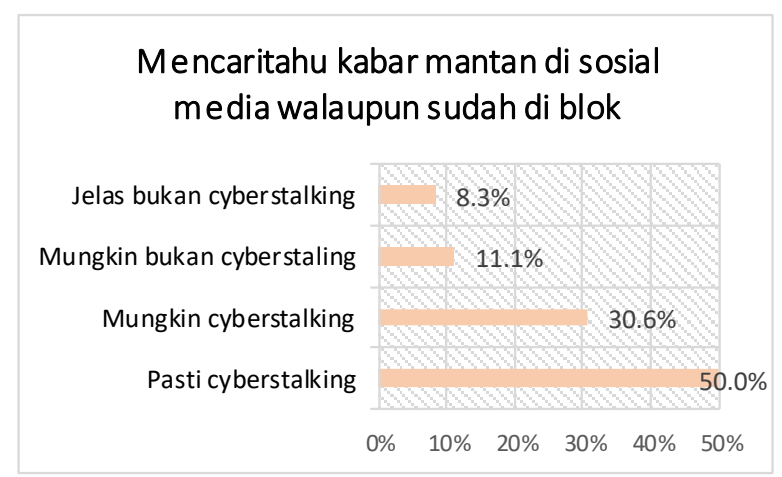

Sebagian besar responden telah mengetahui bahwa untuk situasi hipotesis pada pernyataan ini bukan indikasi cyberstalking, hanya 3 responden yang memilih mungkin cyberstalking, 2 responden perempuan dan 1 responden laki-laki memilih penyataan mungkin cyberstalking.

Tabel 8 Data Hasil Respon Sudut Pandang Mantan

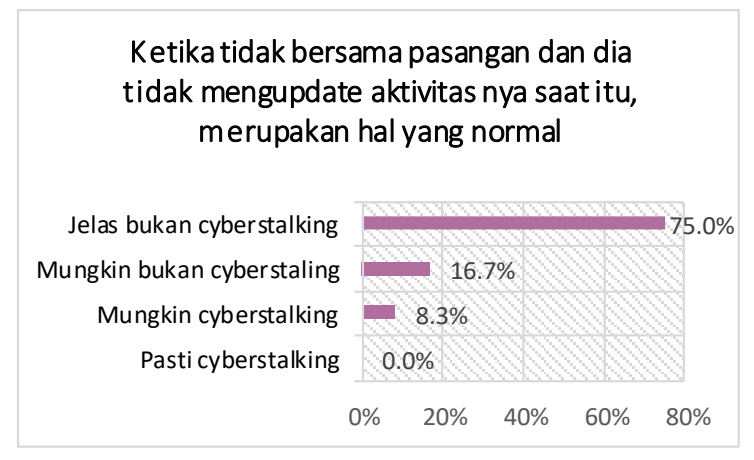

$80 \%$ responden memilih melabelkan situasi hipotesis ini sebagai cyberstalking. 1 responden laki-laki dan 2 responden perempuan menyatakan bahwa hal ini jelas bukan cyberstalking, dan 4 responden perempuan memililih mungkin cyberstalking. Pernyataan ini memiliki indikator cyberstalking menganggu.

Tabel 9 Data Hasil Respon Sudut Pandang Mantan

Total 35 dari 36 responden

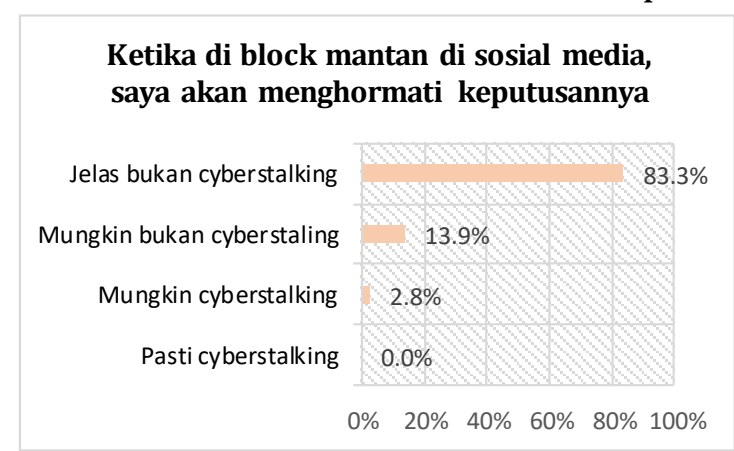


melabelkan situasi hipotesis ini bukan Cyberstalking, Cybercrime, perempuan yang memilih melabelkan pernyataan ini mungkin cyberstalking.

Tabel 10 Data Hasil Respon Sudut Pandang Mantan

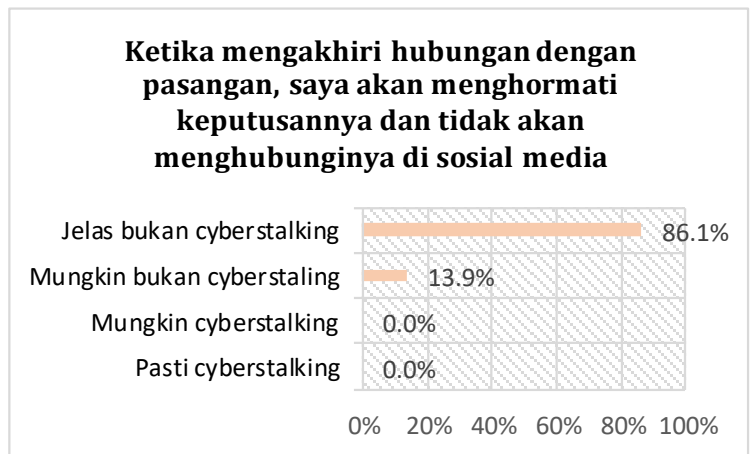

Hasil pada situasi hipotesis ini tegolong unik, di mana total respon setiap pilihan jawaban sama rata. Responden laki-laki cenderung melabelkan situasi ini bukan cyberstalking dengan perbandingan 6 responden yang tidak setuju dan 3 responden yang setuju. Responden perempuan cenderung memilih untuk melabelkan pernyataan ini sebagai cyberstalking, dengan perbandingan yang sangat tipis 15:12 respon. Angket ini memiliki indikator intimidasi dalam pernyataannya.

Tabel 11 Data Hasil Respon Sudut Pandang Mantan

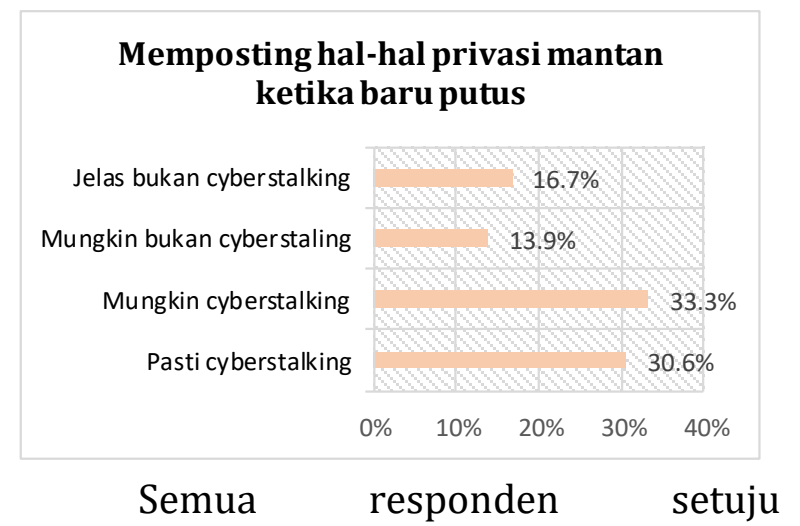

melabelkan situsi hipotesis ini sebagai bukan indikasi cyberstalking.
Tabel 12 Data Hasil Respon Sudut Pandang Mantan Mayoritas respon melabelkan situasi

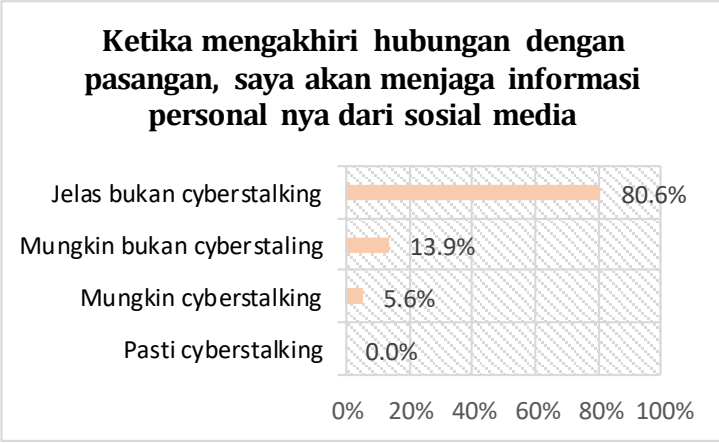

hipotesis ini sebagai indikasi cyberstalking, terdapat indikator cyberstalking intimidasi dan menganggu pada pernyataan ini, representatif responden laki-laki dan perempuan memiliki persepsi yang berbeda di mana responden laki-laki 6 dari 9 menyatakan bahwa ini bukan termasuk cyberstalking sedangkan 20 dari 27 responden perempuan menyatakan bahwa ini adalah cyberstalking.

Tabel 13 Data Hasil Respon Sudut Pandang Mantan 34 dari total 36 responden

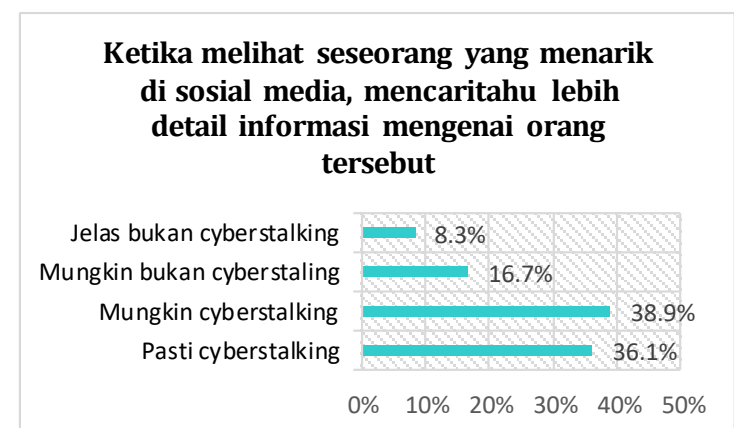

melabelkan situasi hipotesis ini sebagai bukan indikasi cyberstalking. 1 responden laki-laki dan 1 responden perempuan menyatakan bahwa pernyataan ini sebagai mungkin cyberstalking.

Tabel 14 Data Hasil Sudut Pandang Orang Asing

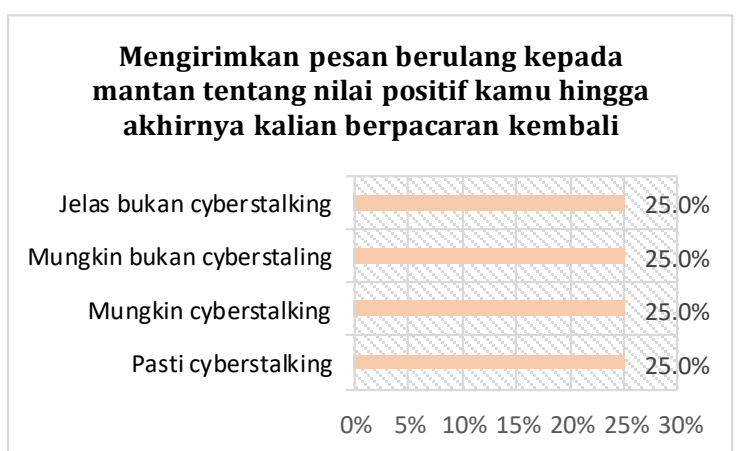


Mayoritas respon melabelkan pernyataan ini sebagai indikasi cyberstalking. 3 dari 9 responden laki-laki menyatakan pernyataan ini bukan cyberstalking, sedangkan responden perempuan yang juga menyatakan bahwa pernyataan ini bukan cyberstalking adalah 6 dari 27 responden.

Tabel 15 Data Hasil Sudut Pandang Orang Asing

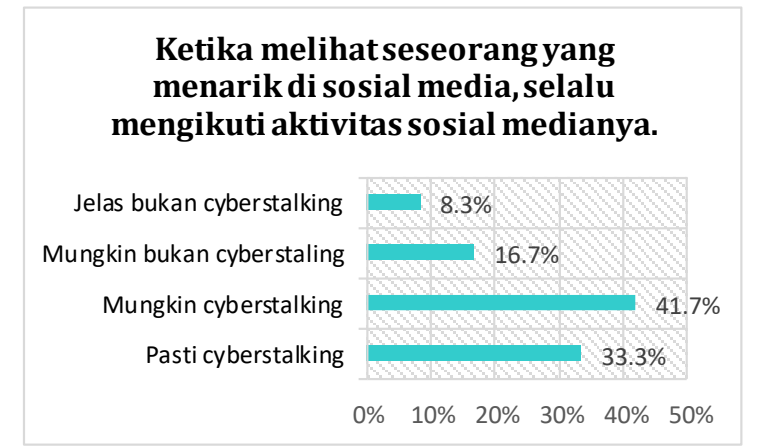

Semua responden setuju melabelkan situsi hipotesis ini sebagai bukan indikasi cyberstalking.

Tabel 16 Data Hasil Sudut Pandang Orang Asing

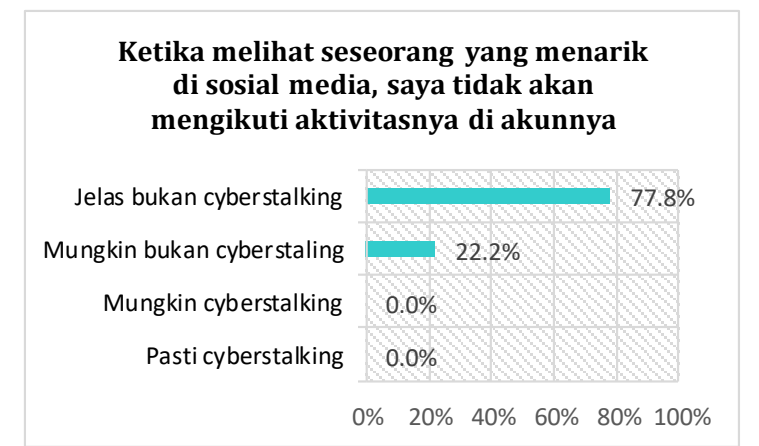

Sebagian besar responden melabelkan bahwa situasi hipotesis ini sebagai cyberstalking. 2 dari 9 responden laki-laki melabelkan pernyataan ini sebagai bukan cyberstalking sedangkan untuk responden perempuan 7 dari 27.
Tabel 17 Data Hasil Sudut Pandang Orang Asing

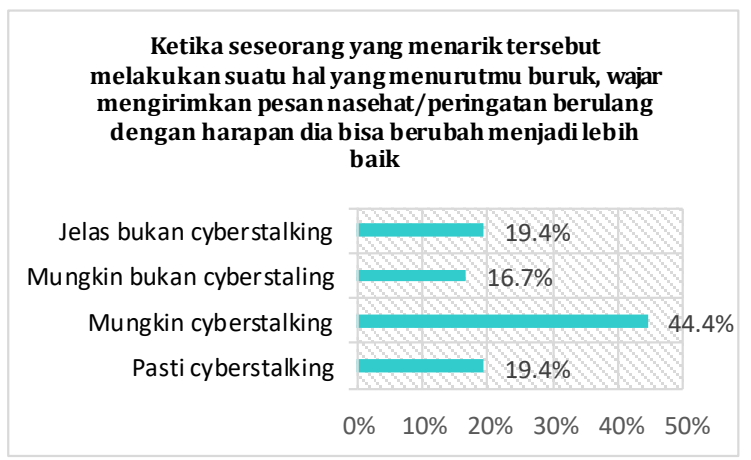

Semua responden setuju melabelkan situasi hipotesis ini sebagai bukan indikasi cyberstalking.

Tabel 18 Data Hasil Sudut Pandang Orang Asing

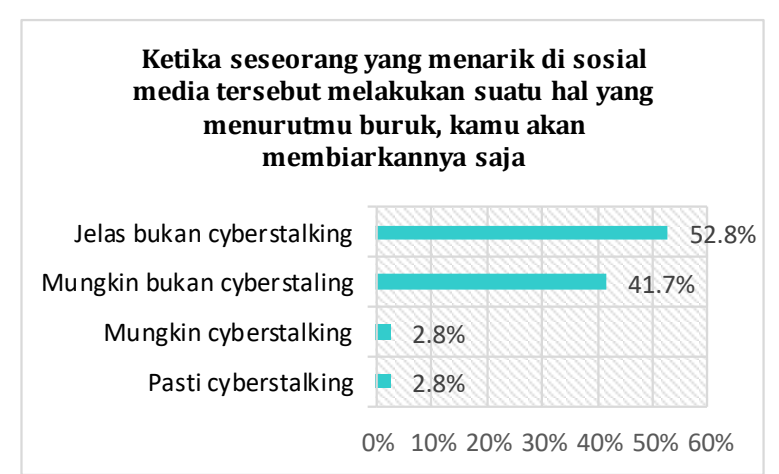

63.8\% responden memberikan label cyberstalking pada pernyataan ini, indikator cyberstalking mengendalikan, mengintimidasi dan menganggu terdapat pada situasi hipotesis ini. Responden lakilaki memiliki persepsi yang berbeda, di mana 5 dari 9 responden menyatakan bahwa penyataan ini bukan cyberstalking. Tabel 19 Data Hasil Sudut Pandang Orang Asing

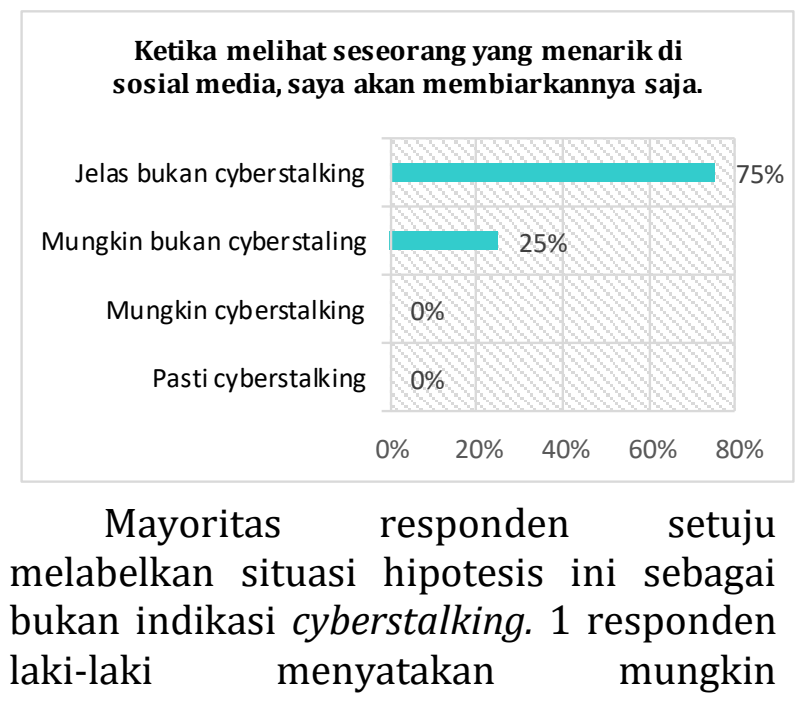


cyberstalking dan 1 responden perempuan menyatakan pasti cyberstalking. Pada angket yang disebarkan, situasi hipotesis dalam pernyataan angket dibagi menjadi tiga sudut pandang yaitu sebagi pasangan, mantan pacar dan orang asing. 9 pernyataan favorable dan 9 pernyataan unfavorable, indikator cyberstalking yang digunakan dalam angket yaitu mengendalikan, mengintimidasi, mengancam, memaksa, dan menganggu.

Kasus-kasus cyberstalking, korban mengetahui pelaku cyberstalking tersebut yang sebagian besar adalah pasangannya saat itu atau mantan pacar. Pasangan yang menguntit memiliki tingkat bahaya lebih tinggi selain akan menerima perlakuan seperti diikuti, diancam atau dilecehkan juga karena karena adanya dominasi fisik. Kasus di mana korban dan pelaku tidak saling mengenal secara langsung, biasanya terjadi kepada selebriti atau seseorang yang cukup dikenal publik. Informasi pribadi yang tersebar online telah mengaburkan batas-batas antara hal yang tidak dapat didekati dan dapat diakses (Abshier et al, 2012).

Hasil angket persepsi cyberstalking pada sudut pandang pasangan, indikator cyberstalking seperti mengendalikan, mengganggu dan mengancam adalah halhal yang masih dijustifikasi oleh responden, pada angket pernyataan pertama yang menyatakan "tidak memperbolehkan pasangan chatting dengan lawan jenis/mantan pacar di sosial media" hanya satu responden yang melabelkan pernyataan ini sebagai "pasti cyberstalking" 23 responden dari total 36 memiliki persepsi bahwa pernyataan ini bukan indikasi cyberstalking.

Pernyataan ketiga "ketika pasangan tidak bisa diawasi di sosial media saat tidak bersama, saya akan komplain agar dia tidak melakukan hal yang sama lagi" persepsi responden di pernyataan ini tersebar dengan rata, mengejutkannya respon yang menganggap pernyataan ini memiliki indikasi cyberstalking dan bukan cyberstalking 18:18 dari total responden 36 mahasiswa.

Mengendalikan adalah salah satu bagian dari cyber dating abuse (CDA) di mana mengacu pada perilaku memantau atau mengendalikan, misalnya sering mengunjungi sosial media korban (Borrajo, Gámez-guadix, \& Calvete, 2015).

Hasil angket persepsi cyberstalking pada sudut pandang mantan pacar, pada pernyataan "mencaritahu kabar mantan di sosial media walaupun sudah di blok" dan "memposting hal-hal privasi mantan ketika baru putus," mayoritas responden memberikan persepsi bahwa dua pernyataan tersebut memiliki indikasi cyberstalking.

Pada pernyataan "mengirimkan pesan berulang kepada mantan tentang nilai positif kamu hingga akhirnya kalian berpacaran kembali" hasil respon yang didapatkan di empat kategori berjumlah sama rata, penempatan kata "positif" di samping "berulang" memberikan persepsi yang berbeda pada setiap responden. Pelaku cyberstalking melakukan aksinya ketika hubungan dengan pasangan berakhir. Balas dendam, amarah dam keinginan untuk mempetahankan hubungan adalah hal-hal yang menjadi alasan pelaku melakukan cyberstalking pada mantan pasangannya (Abshier et al, 2012).

Hasil angket persepsi cyberstalking pada sudut pandang orang asing, pada pernyataan "ketika melihat seseorang yang menarik di sosial media, mencaritahu lebih detail informasi mengenai orang tersebut," "ketika melihat seseorang yang menarik di sosial media, selalu mengikuti aktivitas sosial medianya" dan "ketika seseorang yang menarik tersebut melakukan suatu hal yang menurutmu buruk, wajar mengirimkan pesan nasehat/peringatan berulang dengan harapan dia bisa berubah menjadi lebih baik." Berdasarkan pernyataan-pernyataan tersebut sebagian besar responden melabelkan indikasi cyberstalking, hal ini sesuai dengan 
indikator cyberstalking menganggu, mengintimidasi dan mengontrol yang terdapat pada pernyataan di atas.

Cyberstalking yang dilakukan kepada orang asing, biasanya korban adalah seorang selebriti atau seseorang yang cukup dikenal banyak orang. Pelaku tipe Intimate cyberstalker, melakukan aksinya dengan tujuan ingin memiliki hubungan dengan korbannya, rasa suka yang berlebih hingga menimbulkan obsesi (Octora, 2019).

Pelaku merasa aman dalam melakukan perilaku cyberstalking karena berlindung pada anonimitas dalam internet. Pelaku bisa melakukan aksinya dengan rasa nyaman di rumah tanpa harus mengutit secara langsung di dunia nyata. Anonimitas menjadi poin utama pelaku berani melakukan perilaku cyberstalking (Hamin, \& Rosli, 2018).

Tidak ada perbedaan perilaku cyberstalking antara pelaku laki-laki atau perempuan, akan tetapi bagaimana perempuan dan laki-laki melihat perilaku cyberstalking berbeda satu sama lain. Perempuan lebih mudah melihat perilaku cyberstalking, hal ini sesuai dengan steriotip sosial perempuan yang empati, simpati dan lebih sensitif dalam menyadari bahaya disekitarnya sedangkan laki-laki dinilai sebagai aggressor pada kasus-kasus sejenis (Ahlgrim \& Terrance, 2018).

\section{SIMPULAN}

Berdasarkan hasil data yang telah di dapatkan, mahasiswa ilmu forensik cenderung telah memiliki persepsi yang benar mengenai konsep cyberstalking, pada pernyataan angket persepsi dari sudut pandang mantan pacar dan orang asing, responden telah mengetahui dengan sangat baik, situasi hipotesis seperti apa saja yang diklasifikasikan sebagai cyberstalking, hanya pada persepsi dari sudut pandang pasangan dari tiga pernyataan yang memiliki indikasi cyberstalking, hanya satu pernyataan yang memiliki respon yang benar.
Indonesia sebagai Negara yang menganut budaya patriarki yang kental, memiliki norma sosial yang telah tertanam sejak dulu bahwa dalam berpasangan, merupakan hal yang normal ketika lakilaki mengontrol atau memberikan batasan-batasan tertentu kepada pasangannya. Hal ini dibuktikan dengan responden laki-laki mayoritas memiliki persepsi bahwa situasi-situasi hipotesis yang memiliki indikator mengendalikan dan mengintimidasi bukan perilaku cyberstalking. Belum ada undang-undang yang mengantur tentang cyberstalking, akan tetapi UU ITE Pasal 27 ayat (1) sampai (4) bisa digunakan untuk menghadapi tindak kriminal terhadap Informasi dan Transaksi Elektronik.

\section{DAFTAR PUSTAKA}

Abshier, M., Allen, K., Anderson, K. \& Awbrey, B. (2012). Prevention of cyberstalking: A review of the literature. Portland State University. Criminology and Criminal Justice Senior Capston.

Ahlgrim, B., \& Terrance, C. (2018). Perceptions of Cyberstalking: Impact of Perpetrator Gender and Cyberstalker / Victim Relationship. 1-20. https://doi.org/10.1177/088626051878459 0

Alexy, E. M., Burgess, A. W., \& Baker, T. (2005). Perceptions of Cyberstalking Among College Students. 279-289. https://doi.org/10.1093/brieftreatment/mhi020

Ambarsari, B. T., Fadhila, R. N., \& Christiana, R. (2017). Peer-group Counseling untuk Mengurangi Intensitas Munculnya Perilaku Cyberstalking pada Remaja. 1(1), 118-125.

APJII, A. J. P. I. I. (2019). Infografis Penetrasi \& Perilaku Pengguna Internet Indonesia. Teknopreuner, 1(Hasil Survei Penetrasi dan Perilaku Pengguna Internet Indonesia 2018), 1-39.

Begotti, T., \& Maran, D. A. (2019). Characteristics of Cyberstalking Behavior, Consequences, and Coping Strategies: A Cross- Sectional Study in a Sample of Italian University Students.

Borrajo, E., Gámez-guadix, M., \& Calvete, E. (2015). Justification beliefs of violence, myths about love and cyber dating abuse. 27(4), 327-333. https://doi.org/10.7334/psicothema2015.5 9

Cavezza, C., \& Mcewan, T. E. (2015). Cyberstalking versus Off-line Stalking in a Forensic Sample. 
Ainun Jaryah Bahrir, Studi Deskriptif: Persepsi Mahasiswa Ilmu Forensik terhadap Cybestalking

Psychology, Crime \& Law, o(0), 1-16. https://doi.org/10.1080/1068316X.2014.89 3334Contoh-contoh penulisan dapat dilihat pada penjelasan setiap jenis pustaka yang layak dirujuk.

Hamin, Z., Rosli, W. (2018). Cloaked By Cyber Space : A Legal Response to the Risks of Cyber Stalking in Malaysia. 12(June), 316-332. https://doi.org/10.5281/zenodo.1467931

Kusuma, Wijaya. 2011. Penelitian Tindakan Kelas. Jakarta: PT Indeks.

Maran, D., \& Begotti, T. (2019). Prevalence of Cyberstalking and Previous Offline Victimization in a Sample of Italian. https://doi.org/10.3390/socsci8010030

Merdeka. Indonesia Jadi Negara Pengguna Internet Terbesar ke-5 Dunia. http://www.merdeka.com. (12 Agustus 2019).

Nurmila, N. (2015). Pemahaman Agama dan Pembentukan Budaya. KARSA, 1-16.
Octora, R. (2019). Problematika pengaturan cyberstalking (penguntitan di dunia maya) dengan menggunakan annonymous account pada sosial media 11(November), 77-96.

Reyns, B.W.; Henson, B.; Fisher, B.S. (2012). Stalking in the Twilight Zone: Extent of Cyberstalking Victimization and Offending among College Students. Deviant Behav. 2012, 33, 1-25.

Sholikhah, A. (2016). Statistik Deskriptif. 10(2), 342-362.

Tennakoon, H., Saridakis, G., \& Mohammed, A. (2017). Child online safety and parental intervention: a study of Sri Lankan internet users. https://doi.org/10.1108/ITP-092016-0213

Yusaputra, M. I. S. A., Fitria, D., Sari, K., Utama, R. R., \& Husnuzan, A. (2018). The opinion of communication science students on cyberstalking phenomen in social media. 